\title{
The Determination of Total Metabolism in the Mouse
}

\author{
By A. D. DEWAR and W. H. NEWTON \\ Physiological Laboratory, Department of Physiology and Histology, \\ University of Liverpool
}

(Received 31 March 1948)

The apparatus to be described was designed to investigate certain phenomena of pregnancy by enabling $(a)$ the measurement of the total ingesta and excreta of a mouse, including the exchange of water and gases, for periods of approximately $24 \mathrm{hr}$. under conditions as normal as possible, and $(b)$ the repetition of such daily measurements for long periods (up to the duration of pregnancy) with a minimum break between successive daily runs. It was hoped to obtain a complete picture of the metabolism of the mouse, i.e. the daily intake of foodstuffs, their utilization, the water balance and the average metabolic rate. This has proved to be possible, though only non-pregnant animals have so far been used.

The considerable work involved is offset by the advantage of being able to measure interdependent factors simultaneously; furthermore, the relatively long periods of measurement, usually impracticable in specialized metabolic studies, smooth out those sporadic fluctuations of metabolic rate which would otherwise require for their elucidation numerous repeated determinations. For similar reasons, it is to be expected that a series of consecutive long-period determinations will reveal gradual changes not easily demonstrable otherwise.

The main advantage of a closed-circuit design for such studies, over the more frequently used open-train Haldane-Pembrey type, is that all determinations, including that of oxygen utilization, are made by direct measurement. The balance of all such separately determined factors therefore provides an infallible guide to the accuracy of the apparatus. No inaccuracy can be masked by the indirect determination of any factor by difference.

The construction of an apparatus fulfilling the above requirements, although straightforward in principle, was beset by many technical difficulties. It is felt, therefore, that a detailed description of the design now in use may be of value to those undertaking similar work. The authors are unaware of any previous published description of such an apparatus, although the closed-circuit form with measurement of water excretion has been used for mice by Aszodi (1921), Barbour \& Trace (1937) and Newton (1937). Total metabolism studies in man, including the intake and utilization of foodstuffs, were conducted by Benedict \& Milner (1907). Their method of obtaining food balance was, however, by means of the elementary composition of total ingesta and excreta. 
METHODS

\section{Metabolism apparatus}

General description. Fig. $\mathrm{I}$ is a plan of the apparatus. Air from the pump is directed by means of the Schüster-type valve at $A$ through the mouse chamber and thence through water- and $\mathrm{CO}_{2}$-absorption tubes and another valve $(B)$ back to the pump.

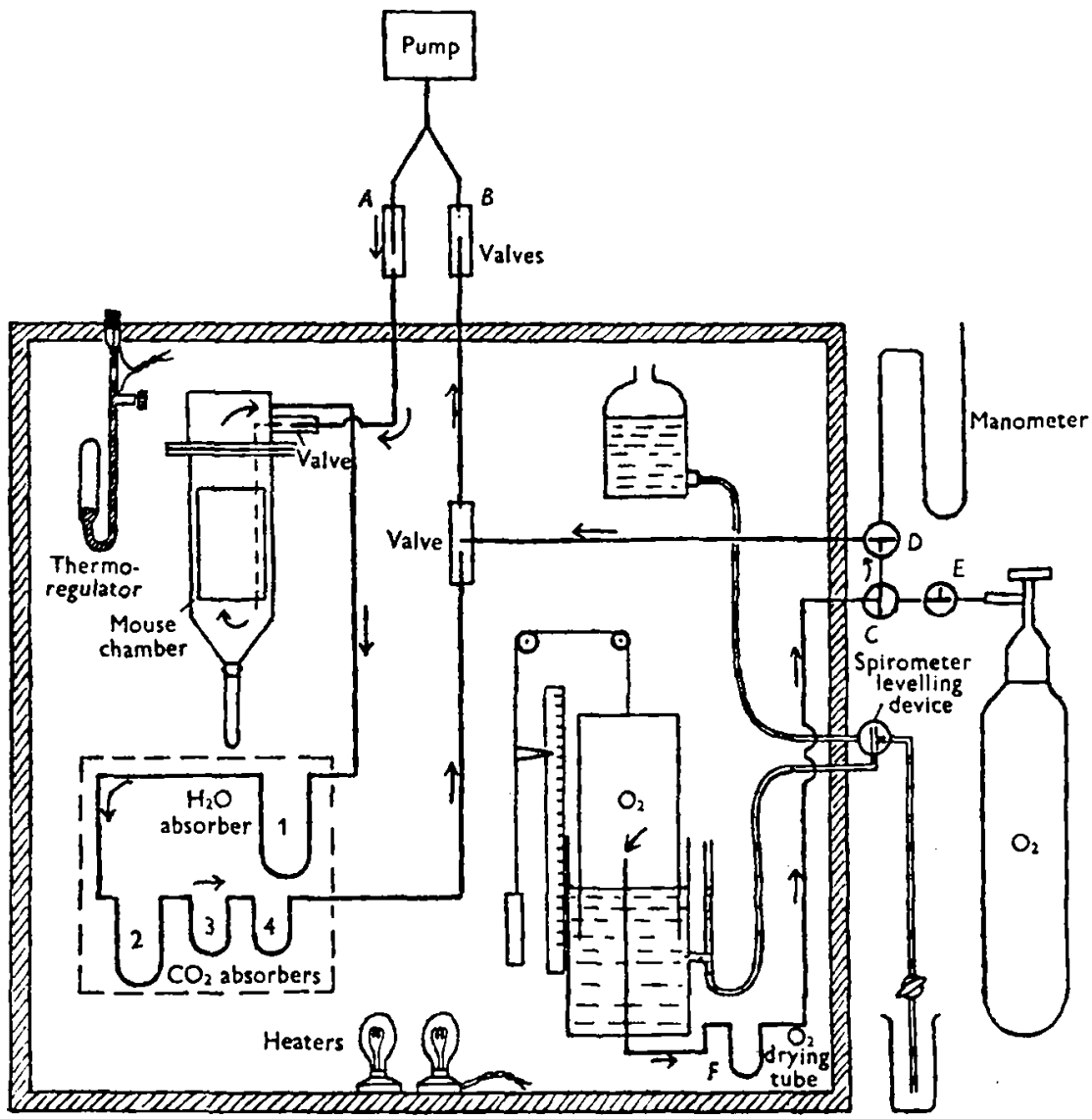

Fig. I. General plan of mouse metabolism apparatus.

Oxygen, to replace that used up in the chamber, enters by a side tube from the graduated spirometer, having first been dried by the water absorption tube $F$. Two three-way taps in this side tube provide for filling the spirometer $(\operatorname{tap} C)$ or for connecting a water manometer to the circuit $(\operatorname{tap} D)$. A third tap $(E)$ permits the circuit or the spirometer to be opened to atmospheric air. All connecting tubes are of glass. Permanent junctions are made with stout rubber tubing sealed to the glass at each end with rubber cement (Bostik B, B.B. Chemical Co. Ltd., Leicester).

The whole, with the exception of the pump, its valves, the manometer and the three taps, is enclosed in a heat-insulated box $\left(2 \frac{3}{4} \times 1 \times 3 \frac{1}{6} \mathrm{ft}\right.$.) maintained at a constant temperature by means of a thermostat and an electric heating bulb. An additional set 
of heating bulbs on a separate circuit can be switched on to raise the temperature within the box rapidly to the required level at the start of an experiment. The whole front of the box is removable and is provided with a double glazed window which permits a view of the mouse in its chamber

The mouse chamber. This is illustrated in Fig. 2. It is constructed of a chromiumplated brass cylinder $(17.5 \mathrm{~cm}$. long and $8 \mathrm{~cm}$. diam.). This is fitted with a Perspex (Imperial Chemical Industries Ltd.) window sealed in position with rubber cement. The lower end is funnel-shaped, and to it can be attached by means of a rubber stopper a 6 in. test-tube to collect the urine. A lid of the same diameter as the cylinder has a flange of $17 \mathrm{~cm}$. diam. which connects with a similar flange on the chamber. Sealing is effected by means of a rubber washer and six wing nuts and bolts. Several types of washer have been tried; by far the most effective are those made of cat inner-tube rubber, and large enough to overlap the flanges inside and outside. With the lid firmly but not forcibly screwed down, a perfect airtight junction is obtained (see Note, p. 139).

Fitting into the chamber is a removable 'grid' comprising ( $a$ ) a fine-mesh wire basket to collect the faeces, (b) the mouse platform and $(c)$ a roof, the two last consisting of a $\mathrm{I} \mathrm{cm}$. wire grille. The roof supports the drinking water bulb and limits the movements of the mouse. Basket, platform and roof are supported by two upright wires, to one of which the food box can be attached.

Resting on the floor of the chamber below the grid is a removable brass funnel which serves to collect, and permit the

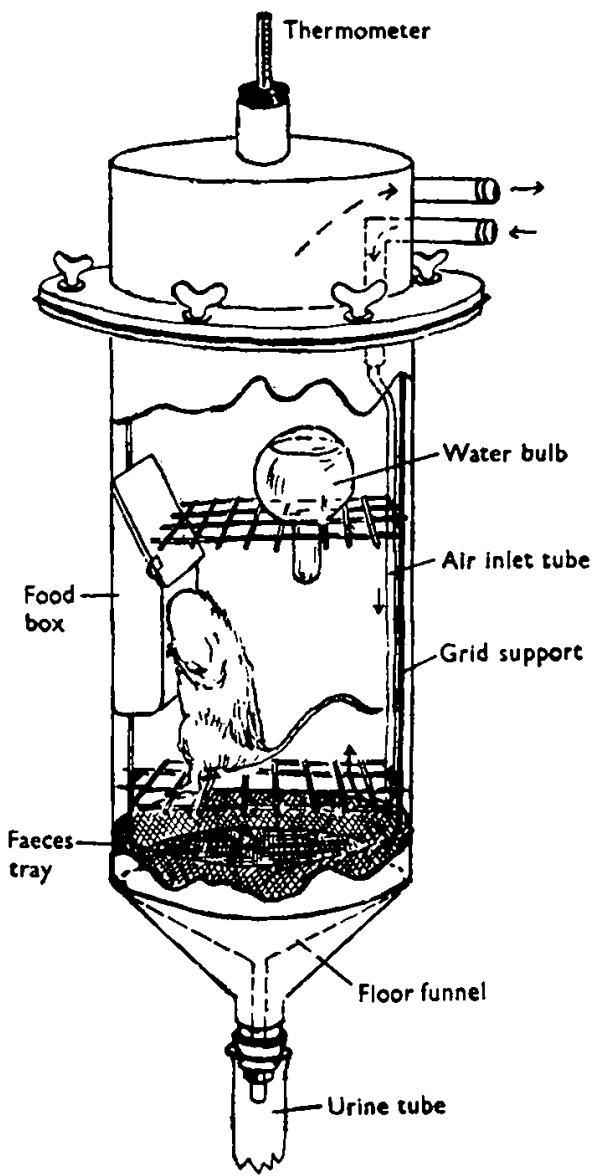

Fig. 2. Diagram of mouse chamber; a portion of the wall containing the window is cut away to show contents. weighing of, any drops of urine or traces of spilt diet present at the end of the run. The neck of the funnel passes loosely through the floor and projects into the urine tube.

The air inlet is a metal tube of $0.8 \mathrm{~mm}$. bore passing through the side of the lid, and turning downwards at right angles. A glass tube carries the inlet to just below the mouse platform, passing through the grille against the chamber wall. A valve in the inlet tube prevents any possibility of back flow of the air current. The air outlet is a short tube above the inlet, flush internally with the chamber (lid) wall.

The total capacity of the chamber is $c$. I l. The dimensions of the mouse 'room' are $8.5 \mathrm{~cm}$. high (between platform and roof) by $7 \mathrm{~cm}$. diam. 
The food box. The box, shown in Fig. 2, is constructed of chromium-plated thin metal. An opening in the front $(c .1 \cdot 5 \mathrm{~cm}$. diam.) just admits the mouse's head, while two small projections at each side of the opening act as rests for the forepaws. The level of the box is adjusted so that the mouse is just able to stand on the grille with its head in the aperture. A removable lid allows the powdered diet to be introduced and packed down fairly firmly to the lower level of the inward-and downward-curving lower lip of the head opening. Spilling from such a container is reduced to a minimum, although inevitably there is some scattering owing to the powdered diet adhering to the animal's snout. The estimation of spillage is described below.

The absorption tubes. These consist of four glass $U$ tubes fitted with stopcocks. Tubes $I$ and 2 (Fig. $I$ ) are of 6 in. and tubes 3 and 4 of 4 in. size. Tubes $I$ and 4 are filled with anhydrous magnesium perchlorate (Anhydrone, British Drug Houses Ltd.), tube I to remove water from the mouse chamber, tube 4 to remove water evolved in tubes 2 and 3. The latter contain soda asbestos (Carbosorb brand, British Drug Houses Ltd., 4-10 mesh) which has proved the most efficient reagent tried for the absorption of $\mathrm{CO}_{2}{ }^{*}$. A tendency for the proximal end of the first $\mathrm{CO}_{2}$ absorption tube to become partially blocked, owing to dissolution of the granules where the reaction is most intense, is overcome by packing the granules in this limb around fine glass tubes of varying lengths. The absorption tubes, after being weighed, are connected and clipped to a wooden frame and can be rapidly fitted into the circuit.

The spirometer. The bell is of Perspex, and has a capacity of about 21 . It is supported by a nylon thread running over two pulleys and counterbalanced by a weight sufficient to balance the bell when nearly empty. A pointer attached to the thread above the counterweight moves over a linear scale calibrated in terms of volume by means of a Hempel burette. Readings can be made to the nearest $0.5 \mathrm{~mm} .(c .5 \mathrm{ml}$.), and are adjusted to N.T.P., allowance being made for the zero error of the spirometer and for water-vapour pressure.

The tank of the spirometer contains a $0.02 \%$ solution of mercuric chloride. With plain water it was found that organisms grew in the tank and on the sides of the bell. Over $24 \mathrm{hr}$. the growths utilized a small but definite quantity of oxygen. The level of water in the tank is indicated by a boiler gauge, and can be adjusted to a zero mark without opening the constant temperature box. An outside tap allows water to be removed from the tank or added to it from a reservoir within the box.

The pump. The most efficient and reliable pump for long periods of work has proved to be a single Dale-Schüster perfusion pump operated by an electric motor. With a speed of 60 r.p.m. and a stroke of $6.5 \mathrm{~mm}$., it has an effective output of about $360 \mathrm{ml} . / \mathrm{min}$., i.e. the air in the chamber is replaced once in $3 \mathrm{~min}$. Between strokes there is a fluctuation in pressure in the apparatus of about $4 \mathrm{~cm}$. water, but this does not appear to disturb the mouse in any way. A marked increase in the pressure fluctuations during a run indicates an increased resistance to the air flow in the circuit, probably due to a partial blocking of the first $\mathrm{CO}_{2}$ absorption tube (tube 2 in Fig. 1 ). Detection of leaks. All temporary junctions of rubber tubing are carefully inspected

- After $824 \mathrm{hr}$. run, the $\mathrm{CO}_{2}$ content of the mouse chamber is less than $0.5 \%$. 
before use and either wired in position or doubly sealed by a second overlapping collar of thinner tubing which can be rolled into position. Before use the apparatus is tested by assembling it completely and observing whether, after several hours with the pump on, there is any loss of oxygen from the spirometer. A leak developing during an experiment reveals itself by the error of weight balance consequent on a false oxygen consumption (see p. 13r).

\section{Food}

The percentage composition of the diet (MET 2) designed for use with this apparatus is: dried whole milk 25, casein (light white, British Drug Houses Ltd.) 19, rice starch 46, salt mixture 5, arachis oil 2, cod-liver oil I, wheat germ (Bemax, Vitamins Ltd.) 2. Young mice fed on this diet show good growth rates, and normal pregnancy and lactation with good growth of litters occur when adult females are fed with the unsupplemented diet from before conception.

Analysis of the dry diet gave the following percentage composition: protein $24^{\circ} 9$ (N 3.9), carbohydrate $57^{\cdot}$, fat 10.3. Nitrogen was estimated by the micro-Kjeldahl method and converted to protein by using the factor 6.38 (since the protein consisted mainly of casein containing $15.67 \%$ nitrogen), carbohydrate by estimation of reducing sugars after hydrolysis, and fat by weighing the total ether-soluble material. Food intake is calculated on the basis of dry material, but $\mathrm{I} g$. of diet contains $0.008 \mathrm{~g}$. of water bound as water of crystallization, and this must be accounted for when estimating water balance. A series of seven separate determinations of the fat content of one batch of the diet gave an average of $10.31 \%$ (range $9.87-10.96 \%$ ). Each time $c .2 \mathrm{~g}$. of diet were analysed, that is, roughly the quantity eaten daily by a mouse. Since, in the preparation of a powdered diet, the constituent presenting most difficulty in mixing is fat, these figures indicate a satisfactory degree of homogeneity.

The digestibility of each of the constituent foodstuffs was determined by measuring its faecal excretion in a group of mice fed on the diet and subtracting the amount present in the faeces when the foodstuff in question was omitted from the diet (metabolic faecal material). The difference gives the quantity of unabsorbed foodstuff. In this way it was found that of the total ingested, approx. $0: 65 \%$ carbohydrate, $1 \cdot 4 \%$ fat and $0.8 \%$ protein ${ }^{*}$ were not absorbed.

For the purpose of most experiments, however, a figure for the digestibility of the foodstuffs as defined above is not required, balances of foodstuffs being obtained from the total ingested less the total present in the faeces and the quantities metabolized.

\section{Analysis of the faeces}

It is impossible to interpret the dry material of the faeces accurately in terms of foodstuffs. It must suffice to consider nitrogen as representing protein, total ethersoluble material as fat, and the residual dry matter, after accounting for protein, ash and fat, as carbohydrate.

In experiments with one mouse it is difficult to carry out a complete analysis daily

- Bosshardt \& Barnes (1946), using a different method, obtained a figure of $98 \cdot 3$ for the digestibility of casein. 
owing to the small quantity of faeces available. The composition must therefore be deduced from the daily weight of dry faeces and the average composition of faeces derived from analysis of the faeces collected from several mice fed on the diet. Figures so determined give the composition of dry faeces (diet MET 2) as follows: protein $0.398 \mathrm{~g}$., fat $0.015 \mathrm{~g}$., ash $0.324 \mathrm{~g}$. and carbohydrate $0.263 \mathrm{~g}$. $/ \mathrm{g}$. faeces.

The disadvantages of such a method are $(a)$ that the composition of the faeces may vary in different mice, and $(b)$ that the method of analysis is open to question. Nevertheless, the error involved in the estimation of the total balance of individual foodstuffs will be small. For instance, with carbohydrate; the total present in the faeces represents about $3 \%$ of the total carbohydrate ingested. If the error in the determination of the faecal carbohydrate is as much as $50 \%$, which is unlikely, the consequent error in the total balance will be only $c .1 \times 5 \%$.

Table I. Comparison of values for faecal nitrogen determined directly and calculated from dry weight and average analysis of the faeces

\begin{tabular}{|c|c|c|c|}
\hline \multirow[b]{2}{*}{ Exp. no. } & \multirow{2}{*}{$\begin{array}{c}\text { Weight of } \\
\text { dry faeces } \\
\text { (g.) }\end{array}$} & \multicolumn{2}{|c|}{ Faecal nitrogen } \\
\hline & & $\begin{array}{l}\text { Calculated } \\
\text { (mg.) }\end{array}$ & $\begin{array}{c}\text { Found } \\
\text { (mg.) }\end{array}$ \\
\hline $6 / 3$ & 0.139 & $8 \cdot 6$ & $8 \cdot 0$ \\
\hline $6 / 4$ & 0.197 & $12 \cdot 3$ & $11 \cdot 4$ \\
\hline $7 / 1$ & 0.170 & 10.6 & 10.4 \\
\hline $7 / 2$ & 0.153 & 9.5 & $9 \cdot 0$ \\
\hline $8 / 1$ & 0.102 & $6 \cdot 4$ & $.7 \cdot 0$ \\
\hline $9 / 1$ & 0.145 & 9.0 & $8 \cdot 9$ \\
\hline $9 / 2$ & 0.153 & 9.5 & $8 \cdot 6$ \\
\hline & 0.153 & $9 \cdot 5$ & $9 \cdot 2$ \\
\hline $9 / 4$ & 0.180 & $1 X \cdot 2$ & $13 \cdot 2$ \\
\hline $10 / 1$ & 0.100 & $6 \cdot 2$ & $7 \cdot 0$ \\
\hline Mean & & $9 \cdot 28$ & $9 \cdot 27$ \\
\hline
\end{tabular}

Since the amount of faecal fat is very small, any error in its measurement is of negligible influence on the total fat balance.

With protein, although it is not strictly justifiable to assume that all faecal nitrogen is present in the form of protein, it can be argued that all nitrogen lost from the body represents the loss of an equivalent amount of protein, from the point of view of protein balance. With regard to the objection $(a)$ above, it has been found, as shown in Table $I$, that remarkably good agreement exists between actual nitrogen determinations and values calculated from the dry weight and average analysis of the faeces.

\section{Use of the apparatus}

Conditioning of the mouse. Prior to its use in an experiment the mouse is kept for 3-4 days at the experimental environmental temperature, and fed on the diet MET 2 from the type of container described.

Box temperature. The temperature of the box is maintained at $26 \cdot I^{\circ}$. This temperature has no particular significance apart from the fact that it is sufficiently high to reduce the activity of the mouse but not sufficiently near the critical temperature to 
introduce the special conditions obtaining at that level. According to Herrington (1940), the critical range of temperature for the mouse is $30-33^{\circ}$. For the purposes for which this apparatus was designed the importance of temperature rests in its constancy, in order to exclude the possibility of alterations in the metabolic rate due to environmental changes; leakage from the drinking bulb is also obviated.

Commencement of experiment. The absorption tubes are filled, weighed, mounted on their board, and placed in position in the circuit. The constant temperature box is closed, the spirometer filled and, when the box is at the required temperature, the initial spirometer reading is taken. The following are weighed: the grid (with floor funnel), the urine-collecting tube (containing $2 \mathrm{ml}$. of $c .0 .3 \mathrm{~N}-\mathrm{HCl}$ ), the food box (before as well as after filling) and the filled drinking bulb. The chamber is assembled and the mouse meanwhile weighed after emptying its bladder by pressure. The mouse is placed in the chamber and the latter sealed and placed in the circuit. With taps $C$ and $E$ (Fig. I) arranged so as to close the spirometer but to open the rest of the circuit to the air, the absorption-tube taps are opened. Tap $C$ is then turned so as to close and complete the circuit, the temperature within the mouse chamber and the time are noted and the pump is switched on. It is necessary to note the initial temperature of the air in the mouse chamber, for the expansion caused by raising the temperature to that of the box results in a displacement involving the spirometer reading, and the calculated expansion must be subtracted from the final reading.

End of day's run and recommencement. A second mouse chamber, set of absorption tubes and other components have been prepared and the necessary initial weighings made. At the end of a $24 \mathrm{hr}$. run, the time is taken, the pump switched off* and, after I min. to allow equalization of pressure within the apparatus, the spirometer is read. The box is opened, the absorption tubes closed and the mouse chamber removed and opened. The mouse is weighed, after emptying its bladder by pressure into the urine tube, and the grid (with floor funnel) and the food box with its contents are weighed as quickly as possible to avoid loss of moisture. Meanwhile the spirometer is refilled and the procedure described in the last section repeated with the prepared set of apparatus. Two persons operating in a carefully planned manner take only about $15 \mathrm{~min}$. for the whole change over. The detailed procedure is given in Table 2.

The absorption tubes, urine tube and drinking water bulb are reweighed to give the weights of evaporated water, carbon dioxide, urine and consumed water. The weighed food box and grid are placed in a drying oven at $110^{\circ}$ for $4 \mathrm{hr}$. and then reweighed to give, by difference, the weight of water on the grid and in the faeces and that present in the residual food. From the latter the calculated amount present in the food originally is deducted, the difference representing excreted water absorbed by the residual diet. From the same data the weight of dry food eaten is calculated.

Determination of urinary and faecal nitrogen. The faeces are removed from the grid tray, which together with the floor funnel is carefully washed with slightly acidified water. The washings are added to the urine and made up to a definite volume and their nitrogen content determined by the micro-Kjeldahl technique before and after filtration.

- It is necessary to ensure that the pump diaphragm is always in the same position when spirometer readings are taken. 
The value for the filtered urine gives the urinary nitrogen. The difference between the values for filtered and unfiltered samples represents the nitrogen of spilled diet (which has been shown to be insoluble in urine). The quantity of spilled diet (usually less than $2 \%$ of the food eaten), and therefore the quantity of food eaten, can be calculated. The collected faeces are weighed and their approximate composition calculated as mentioned above. Usually the total nitrogen of the faeces is also directly determined.

\section{Table 2. Procedure for two persons $(A$ and $B$ ) in changing over from} one metabolic outfit to another at the end of $a 24 \mathrm{hr}$. run

\section{Person A}

Person B

Switches off pump and sets at zero mark

Notes time

After I min.............

Sets spirometer and takes reading

Opens box, closes taps of absorption tubes and removes mouse chamber

Removes absorption tubes and replaces them by second set, fills spirometer and closes box

Holds urine tube while.

Weighs mouse in holder

Places mouse in second prepared chamber

Takes initial spirometer reading

Opens box, places chamber in circuit and turns spirometer tap into circuit

Notes chamber temperature, switches on pump and notes time

Closes box

- The spirometer can be filling slowly while the next operation is proceeding.

Measurement of water. The greater part of excreted water is taken up by the first absorption tube or collected in the urine tube. Measurement of water presents the most difficult technical problem of the apparatus. Loss of moisture must be avoided by prompt weighing of the grid and food box on removal from the chamber. The absorption of water by the food while in the chamber creates difficulties in the estimation of both excreted water and food eaten. Only by working on the basis of dry diet as described has the difficulty been overcome. A sample of the food initially introduced is analysed daily for water content to determine accurately the amounts of dry food and water placed in the chamber. Alternatively, before being put in the chamber, the food can be dried by standing it over $\mathrm{H}_{2} \mathrm{SO}_{4}$ in an evacuated desiccator for $48 \mathrm{hr}$. The water present in the residual food at the end of a run then represents only excreted water. To determine the weight of water in the collected urine it is necessary to measure its solid content. The total solids in the filtered diluted urine and chamber washings (see preceding paragraph) are determined by evaporating to dryness a measured volume and weighing the residue. From this figure the weight of dried solids other than faeces and spilled diet from the grid and floor funnel is deducted, the difference representing the solids of the collected urine.

Weighing the mouse. All weighings are made to the nearest mg. on a chemical balance. To restrain its movements, the mouse is weighed in a small tobacco tin which is weighed empty after an initial, or before a final, weighing of the animal. 


\section{Accuracy of the apparatus}

Alcohol checks. It is customary to use alcohol checks as a measure of the accuracy of a metabolism apparatus. These, however, are of limited value since the combustion of alcohol is much more rapid than the metabolic processes of the animal. In a small apparatus it is found that alcohol checks are very difficult to apply and require a specially devised technique. In this instance, the ventilation was insufficient to maintain a flame, the rapid evolution of water caused condensation on the cooler parts of the circuit, while the heat evolved created difficulties in the temperature equilibrium of the apparatus and consequently in the oxygen recording. These difficulties were finally overcome by increasing the pump rate and by using cobalt chloride papers in the tube leading from the chamber to indicate the point at which all the water was absorbed. This took sufficiently long after combustion had ceased for the temperature of the apparatus to become equalized. The pump was stopped when the colour of the edge of the paper nearest to the chamber had changed to bright blue. If air were kept circulating for longer than this, the apparatus became super-dried and high values were obtained for the water of combustion. Similar excessive drying was found by Benedict $\&$ Milner $(1907$, p. 27).

Against the possibility of such a super-drying effect influencing water determinations in the course of metabolism experiments, various tests were carried out, and it was discovered that excessive drying only occurred to any significant extent if no source of water was present in the chamber, a condition obviously inapplicable with mouse, drinking water bulb and urine tube in the chamber.

Table 3. Percentage differences between found and theoretical values in alcohol checks of the accuracy of the metabolism apparatus

$\begin{array}{ccccc}\text { Test no. } & \text { R.Q. } & \mathrm{O}_{2} & \mathrm{CO}_{2} & \mathrm{H}_{2} \mathrm{O} \\ \text { I } & 0.30 & 0.64 & 0.93 & 0.30 \\ 2 & 0.45 & 0.44 & 0.85 & 1.10\end{array}$

The results of two alcohol checks carried out as described are given in Table 3 . The maximum error of any determination was about $1 \%$. The values for the R.Q. of alcohol were 0.665 and 0.664 , as compared with the theoretical 0.667 .

Weight balances. In an apparatus of this nature in which all the factors contributing to the weight change of the animal are directly measured, the accuracy of the apparatus under normal working conditions is indicated by the balance of weights involved. Thus:

Sum of ingesta (oxygen + water + food) - Sum of excreta (carbon dioxide + water + faeces and urine) - Weight change $=0$.

The discrepancies in balance thus obtained in nine $24 \mathrm{hr}$. runs are shown in column 6 of Table 7 (p. 137). The average discrepancy is only $18 \mathrm{mg}$., representing an error in the determination of $0.25 \%$. In no case was the error above $1 \cdot 0 \%$.

Collection of urinary nitrogen. The alcohol checks and weight balances indicate whether measurements of oxygen, carbon dioxide, water and the balance of ingesta 
and excreta are satisfactory. Since determinations of urinary nitrogen play an important part in subsequent calculations, it is important to assess their accuracy. The greater part of the urine drains into the urine-collecting tube containing acid; some, however, remains and dries on the wire tray beneath the mouse platform and on the floor funnel. To investigate whether any nitrogen is lost as ammonia from the dried urine, tests were carried out in which a small quantity of mouse urine (1 ml.) of known nitrogen content was dropped over the floor grille of the mouse chamber which was set up in the complete circuit. The chamber was sealed and air was circulated for $24 \mathrm{hr}$. The chamber was then washed out as after an animal experiment, and the urine and the washings were made up to a definite volume and analysed for nitrogen. It was found that the nitrogen was quantitatively recoverable.

\section{Calculations}

\section{Utilization of results}

From the urinary nitrogen the protein metabolized is determined and its calorific, carbon dioxide, oxygen and water equivalents calculated. The non-protein R.Q. is then calculated by subtracting the oxygen and carbon dioxide of protein metabolism from the total values. From this R.Q., which is calculated to the third decimal place, the calorific value of the non-protein oxygen and its partitioning between fat and carbohydrate are determined, using an extended form of the well-known Lusk-Zuntz and Schumburg tablẹs (Lusk, 1924).

The total energy expenditure, and therefore metabolic rate, can now be calculated, using for the animal's weight the average of the day's initial and final weights.

Using the percentage figures representing the partitioning of oxygen according to the non-protein R.Q., together with appropriate oxygen and water equivalents for fat and carbohydrate combustion, the weights of total fat and carbohydrate metabolized, and the metabolic water involved, are calculated.

From the weights of dry food consumed (having allowed for any scattering as previously described) and of faeces, the quantities of protein, fat and carbohydrate ingested and excreted are calculated. The quantities metabolized being known, the balances of these substances can be determined. It should be pointed out, however, that balances so obtained do not necessarily represent foodstuffs stored by the tissues, since any unabsorbed food in the alimentary tract at the end of the day's experiment will be included as part of the total ingested.

'The water balance of the animal is calculated as the algebraic sum of the water consumed (directly and as bound water in the food), metabolic water (calculated from the quantities of protein, fat and carbohydrate metabolized) and the total water excreted (urine, evaporated water, water in faeces).

\section{Choice of combustion equivalents}

'The oxidation equations from which the equivalents used for the above calculations are obtained are necessarily approximations. The derivations of the factors used here are given below, together with the reasons why, in some cases, they differ slightly from those in common use. 
Carbohydrate. The equivalents are derived from the equation for the combustion of starch:

$$
\begin{aligned}
\mathrm{C}_{6} \mathrm{H}_{10} \mathrm{O}_{5}+6 \mathrm{O}_{2} & =6 \mathrm{CO}_{2}+{ }_{5} \mathrm{H}_{2} \mathrm{O} . \\
\text { I g. carbohydrate } & \equiv \mathrm{I} \cdot \mathrm{I} 85 \mathrm{~g} . \mathrm{O}_{2}=0.829 \mathrm{l} . \\
& \equiv \mathrm{I} \cdot 63 \mathrm{~g} . \mathrm{CO}_{2}=0.829 \mathrm{l} . \\
& \equiv 0.555 \mathrm{~g} . \mathrm{H}_{2} \mathrm{O} . \\
\text { R.Q. } \quad & =\mathrm{I} \cdot 0 .
\end{aligned}
$$

Fat. The R.Q. of mixtures of fat is usually assumed to be 0.707 , and the Lusk-Zuntz and Schumburg oxygen-partitioning tables are based on this assumption. It follows that in calculating fat metabolism from the oxygen consumption, the equivalents used should be derived from an equation giving the same R.Q. A hypothetical combustion of equal quantities of tripalmitin and triolein approximates closely to this requirement:

$$
\begin{aligned}
& \text { Tripalmitin: } \mathrm{C}_{51} \mathrm{H}_{98} \mathrm{O}_{8}+{ }_{72} \cdot 5 \mathrm{O}_{2}=5 \mathrm{ICO}_{2}+49 \mathrm{H}_{2} \mathrm{O} \text {. } \\
& \text { Triolein: } \quad \mathrm{C}_{57} \mathrm{H}_{104} \mathrm{O}_{6}+80 \mathrm{O}_{2}=57 \mathrm{CO}_{2}+{ }_{52} \mathrm{H}_{2} \mathrm{O} \text {. } \\
& \text { I g. mixture } \equiv 2.887 \mathrm{~g} . \mathrm{O}_{2}=2.02 \mathrm{I} \text { l. } \\
& \equiv 2 \cdot 8 \mathrm{rog} \cdot \mathrm{CO}_{2}=\mathrm{I} \cdot 43 \mathrm{Il} \text {. } \\
& \equiv 1 \cdot 076 \mathrm{~g} \text {. } \mathrm{H}_{2} \mathrm{O} \text {. } \\
& \text { R.Q. }=0.708 \text { I. }
\end{aligned}
$$

Protein. The constants usually employed in calculating protein metabolism from urinary nitrogen are those of Loewy (19II), which were obtained in studies of the metabolism of meat protein in the dog. It was considered that for the purpose of calculations connected with this apparatus, factors should be used which more accurately represent the metabolism of the proteins in the diet used. Kriss \& Miller (1934) have published figures for the metabolism of casein by the rat which would appear suitable. However, since the calculation of such figures inevitably involves some assumptions, it was considered that figures calculated on a purely theoretical basis would suffice. Therefore, since the greater part of the protein in the diet (approx. 86\%) consists of casein, urinary nitrogen equivalents for metabolic oxygen, carbon dioxide and water have been calculated from the elementary composition of casein on the assumption that all the nitrogen is eliminated as urea.

The composition of pure dry casein was assumed to be the average of four authoritative values mentioned by Sutermeister \& Browne (1939).

The metabolism of casein is calculated as follows:

from the analytical data

$$
\text { I g. } \mathrm{N} \equiv 3.400 \text { g. C, } 0.446 \text { g. } \mathrm{H} \text { and I.433 g. O, }
$$

if the casein equivalent of I $\mathrm{g}$. $\mathrm{N}$ is metabolized

\begin{tabular}{lcccc} 
& $\mathrm{C}$ & $\mathrm{H}$ & $\mathrm{O}$ & $\mathrm{N}$ \\
Intake & $3.400 \mathrm{~g}$. & $0.446 \mathrm{~g}$. & $1.433 \mathrm{~g}$. & I g. \\
Urinary output calculated as urea & $\mathbf{0 . 4 2 8 \mathrm { g } .}$ & $0.143 \mathrm{~g}$. & $0.571 \mathrm{~g}$. & $\mathbf{1 ~ g .}$ \\
\cline { 2 - 5 } & $\mathbf{2 . 9 7 2 \mathrm { g } .}$ & $0.303 \mathrm{~g}$. & $0.862 \mathrm{~g}$. & - \\
Leaving for combustion & - & $0.108 \mathrm{~g}$. & $0.862 \mathrm{~g}$. & - \\
Deducting intramolecular water & $2.972 \mathrm{~g}$. & $0.195 \mathrm{~g}$. & & -
\end{tabular}


$\mathrm{O}_{2}$ required to oxidize $\mathrm{C}$ and $\mathrm{H}=2 \cdot 972 \mathrm{~g} \cdot \times \frac{82}{12}+0 \cdot 195 \mathrm{~g} \cdot \times 8=9 \cdot 485 \mathrm{~g} .=6 \cdot 639 \mathrm{l}$. $\mathrm{CO}_{2}$ so produced $=(2 \cdot 972 \mathrm{~g} .+7 \cdot 925 \mathrm{~g}$. $)=10 \cdot 897 \mathrm{~g} .=5.5481$.

Water produced $=0.303 \mathrm{~g} . \times 9=2.727 \mathrm{~g}$.

R.Q. $=0.836$.

In Table 4 the equivalents so obtained are compared with others representing protein metabolism. There is reasonable agreement with the figures of Kriss \& Miller (1934).

Table 4. Urinary nitrogen equivalents for $\mathrm{I} g$. nitrogen obtained by different methods

$\begin{array}{lcccc}\quad \text { Method } & \mathrm{O}_{2} & \mathrm{CO}_{2} & \mathrm{H}_{2} \mathrm{O} & \\ & (1 .) & (1 .) & (\mathrm{g} .) & \text { R.Q. } \\ \text { Loewy (1911) } & 5.94 & 4.76 & 2.38 & 0.801 \\ \text { Kriss \& Miller (1934) } & 6.67 & 5.47 & 2.572 & 0.821 \\ \text { Calculation from average composition } & 6.639 & 5.548 & 2.727 & 0.836 \\ \text { of casein } & & & & \end{array}$

Energy value of protein. The above calculation does not permit the determination of the energy equivalent of $\mathrm{I} g$. urinary nitrogen. The figure obtained by Kriss \& Miller (1934) (30.59 Cal./g.) has therefore been adopted.

The complete protocol of a $24 \mathrm{hr}$. run is given in the Appendix (p. 140).

\section{DISCUSSION}

Significance of the respiratory quotient. The method of estimating the utilization of fat and carbohydrate is based upon the assumption that the R.Q. is a true index of the metabolic mixture. Soskin \& Levine (1946) have criticized the use of the R.Q. as such an indicator on the grounds that other reactions involving oxygen and carbon dioxide are occurring simultaneously with the direct combustion of fat and carbohydrate (Schoenheimer, 1942; Werthessen, 1937). It must be admitted that (a) metabolic calculations based on the R.Q. give no direct information about the intermediate reactions involved, and $(b)$ calculations based on short-term observations of gaseous exchange must be interpreted with reserve owing to the various factors which may temporarily mask the true combustions (see Richardson, 1929), one of which is the possibility of the intermediate reactions with 'abnormal' R.Q. demonstrated by Werthessen (1937). However, when metabolic balances are considered, Soskin \& Levine's (1946) contention that the 'classical calculations' are abrogated by interconversions occurring simultaneously with combustions is not valid. For instance, during oxidation of a mixture of fat and carbohydrate, when some of the latter is being converted to fat, the resulting R.Q. is the same as that of a simple combustion mixture consisting of the net substances metabolized, i.e. all the carbohydrate oxidized or converted to fat and the fat oxidized less that quantity formed from carbohydrate. For the purpose of estimating the net utilization of foodstuffs, therefore, simultaneous interconversions do not abrogate the conclusions.

Werthessen's (1937) results show that, although the observed R.Q. at any moment is masked as an indicator of the true metabolic mixture by intermediate reactions, the resultant R.Q. over a period $(20-30 \mathrm{hr}$.) is, in fact, 'normal' This is only to be expected, 
for if energy is ultimately derived from the oxidation of fat, carbohydrate and protein, these combustions must resolve themselves over a sufficiently long period into a utilization of oxygen and excretion of carbon dioxide consistent with the composition of the substances. To assume the contrary is to postulate a progressive retention of parts of the molecules of the foodstuffs, or of carbon dioxide or of oxygen.

In considering the significance of the R.Q. as an indication of the utilization of foodstuffs, therefore, attention must be directed to the duration of the observation period. If it is sufficiently long, side effects due to intermediate reactions will be cancelled out and the resultant R.Q. will be representative of the mean utilization of foodstuffs. It is considered that $24 \mathrm{hr}$. periods of observation for the mouse cover this requirement; R.Q.'s greater than $1 \cdot 0$ or less than 0.7 have not so far been observed.

Accuracy of conversion factors. The balance of ingesta and excreta is measurable with this apparatus to an accuracy of over $99 \%$. This does not mean, however, that the metabolic calculations made from these measurements are necessarily accurate to the same degree, because the various conversion factors employed are approximations, being based upon equations chosen to represent the probable oxidations of fat, protein and carbohydrate.

The metabolism of protein is reasonably accurate, since it is based on nitrogen excretion which can be accurately determined. Since, however, calculations for carbohydrate and fat are dependent upon the accuracy of the nitrogen determinations and their equivalents in oxygen, carbon dioxide and water, it is necessary to see to what extent they are influenced by errors in the measurement of protein.

The effect of error in the nitrogen determination will vary acoording to the total R.Q. If the latter is above that of protein, the effect on calculations of metabolism of carbohydrate will be small, since the variation in the non-protein R.Q. will be offset by equivalent variations in the non-protein oxygen; thus if the error causes an increase in the non-protein R.Q., so favouring a larger carbohydrate metabolism, the subsequent total carbohydrate calculated will be reduced owing to a reduction of the oxygen available for fat and carbohydrate. The influence on calculations of metabolism of fat will be more serious, since errors in non-protein R.Q. and oxygen will, in this case, be added. Similarly with total R.Q.'s below that of protein, errors in nitrogen determinations will have small effect on calculations for fat but will influence calculations for carbohydrate.

In practice it is found that these effects are relatively small. Table 5 shows the effect on calculations of metabolic carbohydrate and fat in two experiments when the urinary nitrogen is increased or decreased by $10 \%$. Despite this large assumed error, which is unlikely to occur in practice, the resulting effects on fat and carbohydrate calculations are not formidable, the variations all being in the second decimal place.

Similarly, errors in the constants chosen as representing protein metabolism will have no drastic effect on the calculations of metabolic carbohydrate and fat. This is illustrated in Table 6, which shows the values obtained when the results of the same experiment are calculated using different protein equivalents.

There is no direct way of assessing the validity of the factors used for estimating fat and carbohydrate metabolism (oxidation oxygen and water equivalents). That no 
serious error is involved in these and other assumptions is indicated by the close correlation shown in each experiment between the observed weight change of the animal and the expected weight change as calculated from the estimated quantities of foodstuffs metabolized.

Table 5. Effect of errors in measurement of protein metabolism on calculations of the metabolism of fat and carbohydrate

\begin{tabular}{|c|c|c|c|c|c|c|c|}
\hline \multirow[b]{3}{*}{$\begin{array}{l}\text { Exp. } \\
\text { no. }\end{array}$} & \multirow[b]{3}{*}{$\begin{array}{l}\text { Total } \\
\text { R.Q. }\end{array}$} & \multicolumn{3}{|c|}{$\begin{array}{c}\text { Carbohydrate } \\
\text { (g.) }\end{array}$} & \multicolumn{3}{|c|}{$\begin{array}{l}\text { Fat } \\
\text { (g.) }\end{array}$} \\
\hline & & \multicolumn{2}{|c|}{ Value } & \multirow[b]{2}{*}{ Difference } & \multicolumn{2}{|c|}{ Value } & \multirow[b]{2}{*}{ Difference } \\
\hline & & True & $\begin{array}{l}\text { With } \\
\mathrm{N} \text { error }\end{array}$ & & True & $\begin{array}{l}\text { With } \\
\mathrm{N} \text { error }\end{array}$ & \\
\hline \multicolumn{8}{|c|}{ Urinary nitrogen increased by $10 \%$} \\
\hline $\begin{array}{l}9 / 2 \\
10 / 1\end{array}$ & $\begin{array}{l}0.930 \\
0.807\end{array}$ & $\begin{array}{l}1 \cdot 330 \\
0.477\end{array}$ & $\begin{array}{l}I \cdot 268 \\
0 \cdot 459\end{array}$ & $\begin{array}{l}-0.032 \\
-0.018\end{array}$ & $\begin{array}{l}0.060 \\
0.423\end{array}$ & $\begin{array}{l}0.005 \\
0.414\end{array}$ & $\begin{array}{l}-0.055 \\
-0.009\end{array}$ \\
\hline \multicolumn{8}{|c|}{ Urinary nitrogen decreased by ro $\%$} \\
\hline $\begin{array}{l}9 / 2 \\
10 / 1\end{array}$ & $\begin{array}{l}0.930 \\
0.807\end{array}$ & $\begin{array}{l}x \cdot 330 \\
0.477\end{array}$ & $\begin{array}{l}\mathrm{I} \cdot 349 \\
0.490\end{array}$ & $\begin{array}{l}+0.019 \\
+0.013\end{array}$ & $\begin{array}{l}0.060 \\
0.423\end{array}$ & $\begin{array}{l}0.078 \\
0.434\end{array}$ & $\begin{array}{l}+0.018 \\
+0.011\end{array}$ \\
\hline
\end{tabular}

Table 6. Calculations of metabolized carbohydrate and fat and of water balance as affected by the use of different protein equivalents

Exp. 9/1 (total R.Q. $=0.921$ ).

\begin{tabular}{lccc}
\multicolumn{1}{c}{$\begin{array}{c}\text { Source of protein } \\
\text { equivalents used }\end{array}$} & $\begin{array}{c}\text { Carbohydrate } \\
\text { (g.) }\end{array}$ & $\begin{array}{c}\text { Fat } \\
\text { (g.) }\end{array}$ & $\begin{array}{c}\text { Water balance } \\
\text { (g.) }\end{array}$ \\
$\begin{array}{l}\text { Calculation from average composition } \\
\text { of casein (see text, p. 133) }\end{array}$ & $1 \cdot 301$ & 0.108 & 0.119 \\
$\begin{array}{l}\text { Kriss \& Miller (1934) } \\
\text { Loewy (191) }\end{array}$ & $1 \cdot 320$ & 0.099 & 0.110 \\
& 1.337 & 0.100 & 0.128
\end{tabular}

'The relationship between body-weight change and foodstuffs metabolized is derived from the water-balance equation of Peters, Kydd \& Lavietes (r933):

$$
\Delta W=\Delta W t+S e-S i+C+F+0.49 P,
$$

where $\Delta W$ and $\Delta W t$ are respectively the balances of water lost and weight gained, $S e$ and $S i$ the weights of solid excreta and ingesta, and $C, F$ and $P$ the weights of metabolized carbohydrate, fat and protein, respectively.

Using the theoretical casein metabolism figures given previously to represent protein instead of those of Loewy (191 r), the protein factor in the equation becomes 0.65 instead of 0.49 . The equation can thus be written:

$$
\Delta W t=\Delta W-S e+S i-C-F-0.65 P .
$$

Alternatively, the change in body weight can be expressed in terms of the individual foodstuff balances, since

$$
\mathrm{Si}=\mathrm{Ci}+\mathrm{Fi}+\mathrm{Pi}+\mathrm{Ri} \text { and } \mathrm{Se}=\mathrm{Ce}+\mathrm{Fe}+\mathrm{Pe}+\mathrm{Re} \text {, }
$$

where $i$ denotes 'ingested', $e$ 'excreted' and $R$ is the residual solid material (salts, etc.) in food, urine and faeces after accounting for carbohydrate, fat and protein. 
Therefore

$$
\Delta W t=\Delta W+(C i-C e-C)+(F i-F e-F)+(R i-R e)+P i-P e-0.65 P .
$$

Since

$$
\begin{gathered}
P i-P e-0.65 P=(P i-P e-P)+0.35 P=\Delta P+0.35 P, \\
\Delta W t=\Delta W+\Delta C+\Delta F+\Delta R+\Delta P+0.35 P .
\end{gathered}
$$

Using either of these equations, the expected weight change of the animal can be calculated. In Table 7 the results of a series of such calculations are compared with the observed weight changes. Column 2 gives the expected weight change as calculated from the metabolic exchanges (equations (1) or (2) above) and is compared with column 3, which expresses the weight change as determined from the original experimental data, namely,

$$
\Delta W t=\text { Sum of ingesta }- \text { Sum of excreta, }
$$

and which itself differs from the observed change in weight (column 4) by the limits of accuracy of the experimental method. The good agreement between columns 2 and 3 (expressed as difference in column 5) is an indication of the accuracy of the conversion factors used in computing metabolic protein, fat, and carbohydrate and water.

Table 7. Comparison of expected and observed body-weight changes

( $\Delta W t$ denotes change in weight.)

(a)

$\Delta W t$ calc. from metabolic exchanges by means of equations ( $I$ )

Exp. or (2), pp. 136-7

no.

$6 / 4$

$7 / 1$

$7 / 2$

$8 / 1$

$9 / 1$

$9 / 2$

$9 / 3$

$9 / 4$

$10 / 1$

Mean (b) $\Delta W t$ calc. from original exp. data, i.e. as difference between sum of ingesta and sum of excreta (g.)

$$
+0.380
$$

$+0.653$

$-0.001$

$-0.246$

$+0.5 \times 3$

$+0.363$

\begin{tabular}{|c|c|c|}
\hline $\begin{array}{c}\text { Observed } \\
\Delta W t \\
\text { (g.) }\end{array}$ & $\begin{array}{c}\text { Difference } \\
(b)-(a) \\
\text { (percentage error } \\
\text { in brackets) } \\
(\mathrm{g} .)\end{array}$ & $\begin{array}{c}\text { Difference } \\
(c)-(b) \\
\text { (percentage error } \\
\text { in brackets) } \\
(\mathrm{g} .)\end{array}$ \\
\hline+0.376 & $-0.021(1 \cdot 14)$ & $-0.004(0.05)$ \\
\hline+0.626 & $-0.015(0.66)$ & $-0.027(0.38)$ \\
\hline-0.007 & $-0.018(0.71)$ & $-0.006(0.08)$ \\
\hline-0.264 & $-0.018(0.84)$ & $-0.018(0.28)$ \\
\hline$+0.53 x$ & $-0.017(0.68)$ & $-0.018(0.24)$ \\
\hline+0.340 & -0.02 I $(0.75)$ & $-0.023(0.30)$ \\
\hline+0.271 & $-0.019(0.70)$ & $-0.010(0.13)$ \\
\hline \multirow{3}{*}{$\begin{array}{l}-0.057 \\
-3.066\end{array}$} & $-0.016(0.76)$ & $-0.028(0.42)$ \\
\hline & $-0.009(0.25)$ & $-0.028(0.40)$ \\
\hline & $-0.017(0.72)$ & $-0.018(0.25)$ \\
\hline
\end{tabular}

$+0.281$

$-0.029$

$-3.038$ (c)

- Percentage error is reckoned as the discrepancy, expressed as percentage, between the sums of the components of the same sign in the equations

(col. 5) $\Delta W-S e+S i-C-F-0.65 P-\Delta W t=0$,

(col. 6) Sum of ingesta - Sum of excrets $-\Delta W t=0$ (see p. 13I).

The $24 \mathrm{hr}$. determination of metabolic rate. It has been pointed out by Barbour \& Trace (1937) and by Herrington (1940) that measurement of the metabolism of mice under 'basal' conditions is difficult, and unnecessary if replaced by measurement under 'standard' conditions which include relatively long periods of determination $(6 \mathrm{hr}$.$) in the post-absorptive state. It is to be expected that with determinations$ continuing for the greater part of $24 \mathrm{hr}$. under constant conditions as described above, activity variations will be reduced to a minimum. Since food is available at all times, 
however, the question arises of the extent to which it is likely to influence the metabolic rate as measured for the long period.

That the availability of food has itself little influence on the constancy of the metabolic rate is shown in Table 8 , which gives the results of ten determinations of metabolic rate and food intake on a single adult female mouse. Despite the variable food

Table 8. Influence of small variations in food intake and in body weight on the metabolic rate (mouse no. 5)

\begin{tabular}{|c|c|c|c|c|}
\hline $\begin{array}{l}\text { Exp. } \\
\text { no. }\end{array}$ & Date & $\begin{array}{l}\text { Food eaten } \\
\text { (g.) }\end{array}$ & $\begin{array}{c}\text { Weight change } \\
\text { (g.) }\end{array}$ & $\begin{array}{l}\text { Metabolic rate } \\
\text { (Cal./g./24 hr.) }\end{array}$ \\
\hline $6 / 2$ & 18 June & $2 \cdot 190$ & +0.090 & 0.360 \\
\hline $6 / 3$ & 19 June & $1 \cdot 484$ & -0.934 & 0.346 \\
\hline $6 / 4$ & 20 June & $2 \cdot 119$ & +0.376 & 0.351 \\
\hline $7 / 1$ & 24 June & 1.412 & +0.626 & 0.341 \\
\hline $7 / 2$ & 25 June & $2 \cdot 464$ & -0.007 & 0.353 \\
\hline $8 / 1$ & 29 June & $\mathrm{r} \cdot 86 \mathrm{i}$ & -0.264 & 0.332 \\
\hline $9 / \mathbf{I}$ & I July & $2 \cdot 344$ & $+0.53^{1}$ & 0.349 \\
\hline $9 / 2$ & 2 July & $2 \cdot 768$ & +0.340 & 0.344 \\
\hline $9 / 3$ & $3 \mathrm{July}$ & 2.709 & +0.271 & $0 \cdot 34^{8}$ \\
\hline $9 / 4$ & 4 July & $2 \cdot 145$ & -0.057 & 0.343 \\
\hline Mean & & tandard devi & & $\begin{array}{c}0.347 \pm 0.0075 \\
(2.2 \%)\end{array}$ \\
\hline
\end{tabular}

Table 9. Influence of considerable variations in food intake and in body weight on the metabolic rate (mouse no. 4)

\begin{tabular}{|c|c|c|c|c|}
\hline $\begin{array}{l}\text { Exp. } \\
\text { no. }\end{array}$ & Date & $\begin{array}{l}\text { Food eaten } \\
\text { (g.) }\end{array}$ & $\begin{array}{l}\text { Weight change } \\
\text { (g.) }\end{array}$ & $\begin{array}{l}\text { Metabolic rate } \\
\text { (Cal./g./24 hr.) }\end{array}$ \\
\hline$I / I$ & 24 April & $1 \cdot 587$ & $-1 \cdot 834$ & 0.279 \\
\hline$I / 2$ & 25 April & 2.740 & +0.315 & 0.346 \\
\hline$x / 3$ & 26 April & $2 \cdot 783$ & -0.040 & 0.361 \\
\hline $2 / 1$ & 5 May & 0 & -3.570 & 0.191 \\
\hline $3 / \mathbf{1}$ & 13 May & $x \cdot 78 r$ & -0.805 & 0.253 \\
\hline $3 / 2$ & 14 May & r.910 & -0.711 & 0.293 \\
\hline $3 / 3$ & I5 May & $2 \cdot 337$ & +0.022 & $0.34 I$ \\
\hline $4 / 1$ & 20 May & $1 \cdot 778$ & $-x \cdot 768$ & 0.274 \\
\hline $4 / 2$ & 21 May & $1 \cdot 987$ & +0.408 & 0.355 \\
\hline $4 / 3$ & 22 May & $2 \cdot 265$ & -1011 & 0.324 \\
\hline $4 / 4$ & 23 May & $2 \cdot 648$ & $+x \cdot 492$ & 0.363 \\
\hline $5 / 2$ & 3 June & 0.628 & $-1 \cdot 102$ & 0.267 \\
\hline $5 / 3$ & 4 June & $2 \cdot 834$ & $+r \cdot 564$ & 0.347 \\
\hline $5 / 4$ & 5 June & $2 \cdot 934$ & +0.075 & 0.342 \\
\hline $5 / 6$ & 6 June & 2.617 & -0.207 & 0.271 \\
\hline $5 / 7$ & 7 June & $2 \cdot 042$ & -0.437 & 0.342 \\
\hline $5 / 8$ & 8 June & $1 \cdot 437$ & $-x \cdot 204$ & 0.321 \\
\hline $5 / 9$ & 9 June & 2.089 & -0.052 & 0.319 \\
\hline \multicolumn{4}{|c|}{ Mean (omitting exp. 2/1) } & $\begin{array}{c}0.317 \pm 0.037^{\circ} \\
(12 \%)\end{array}$ \\
\hline
\end{tabular}

intake the metabolic rate is very constant, showing a standard deviation of only $2 \cdot 2 \%$. The average figure of $0.347 \mathrm{Cal} / \mathrm{g} . / 24 \mathrm{hr}$. (measured at $26 \cdot \mathrm{I}^{\circ}$ ) compares satisfactorily with that of $0.33^{\circ} \mathrm{Cal}$. found at $27.8^{\circ}$ in oophorectomized mice in the post-absorptive state by Barbour \& Trace (1937).

There is evidence, however, that the metabolic rate is likely to vary considerably if the mouse is subject to severe changes in weight following large variations in food 
consumed. Table 9 gives the data obtained for a mouse which showed such weight fluctuations. It indicates a tendency for the metabolic rate to fall when the food intake is insufficient to maintain body weight. This agrees with established facts concerning the influence of the nutritive condition on metabolic rate (Lusk, 1928). The average rate for the six determinations of Table 9 in which no loss in weight occurred is $0.349 \mathrm{Cal} . / \mathrm{g} . / 24 \mathrm{hr}$. with a standard deviation of $\pm 0.008(2.3 \%)$.

\section{SUMMARY}

1. An apparatus designed to measure the intake and utilization of foodstuffs and the water exchange in mice for successive $24 \mathrm{hr}$. periods is described in detail; the balance of total ingesta and excreta so obtained is accurate to within a limit of less than $1 \%$ as compared with the observed weight change of the animal.

2. Utilization of foodstuffs is calculated from the urinary nitrogen and the respiratory exchange. The method is critically discussed. Its validity is supported by evidence based on a comparison of calculated and observed changes in body weight.

3. The metabolic rate as measured over $24 \mathrm{hr}$. periods is relatively constant if body weight is maintained. The taking of food during the period of observation has, of itself, no marked influence on the constancy of the metabolic rate, but the latter falls during the marked loss in weight consequent on a reduced food intake.

Our thanks are due to the Medical Research Council for assistance in defraying the expenses of this work.

\section{REFERENCES}

Aszodi, Z. (1921). Biochem. Z, 113, 70.

Barbour, H. G. \& Trace, J. (1937). Amer. F. Physiol. 118, 77.

Benedict, F. G. \& Milner, R. D. (1907). Bull. U.S. Off. Exp. Stas, no. 175.

Bosshardt, D. K. \& Barnes, R. H. (r946). F. Nutrit. 31, 13.

Herrington, L. P. (1940). Amer. Y. Physiol. 129, 123.

Kriss, M. \& Miller, R. C. (1934). F. Nutrit. 8, 669.

Loewy, A. (1911). Oppenheimers Handbuch der Biochemie des Menschen und der Tiere, 4, pt. I, p. 279. Jena: Gustav Fischer.

Lusk, G. (1924). F. biol. Chem. 59, 41.

Lusk, G. (1928), The Elements of the Science of Nutrition, 4th ed., p. 104. Philadelphia and London: W. B. Saunders Co.

Newton, W. H. (1937). F. Physiol. 89, 421.

Peters, G. P., Kydd, D. M. \& Lavietes, P. H. (1933). F. clin. Invest. 12, 689.

Richardson, H. B. (1929). Physiol. Rev. 9, 61.

Schoenheimer, R. (1942). The Dymamic State of Body Constituents. Cambridge, Massachusetts: Harvard University Press.

Soskin, S. \& Levine, R. (1946). Carbohydrate Metabolism, chap. I1. Chicago: The University Press.

Sutermeister, E. \& Browne, F. L. (1939). Casein and its Industrial Applications, and ed., p. 36 . New York: Reinhold Publ. Corp.

Werthessen, N. (1937). Amer. F. Physiol. r20, $45^{8}$.

Note added in proof. It has recently been found that a washer made of Plasticine makes a reliable seal with less trouble than the rubber washer described on p. 125. 


\section{Appendix}

Item studied

Absorption tube I

Absorption tube 2

Absorption tube 3

Absorption tube 4

Grid and floor funnel

Grid after drying

Dry faeces

Urine tube

Food box and food $t$

Food box after drying

Drinking bulb

Mouse holder

Mouse in holder

Mouse holder

Time

Spirometer vol. (calculated

as dry $\mathrm{O}_{2}$ at N.T.P.)

Chamber temperature

Total nitrogen of urine

Nitrogen of spilled food

Total nitrogen of faeces

\section{Protocol of Exp. 9; day I}

Initial
observation
(1. vii. 47 )

$63.492 \mathrm{~g}$. $70.930 \mathrm{~g}$. $41 \cdot 146 \mathrm{~g}$. $40 \cdot 103 \mathrm{~g}$.

$69.444 \mathrm{~g}$.

$$
\begin{aligned}
& \text { - } \\
& 27.650 \mathrm{~g} . \\
& 54.376 \mathrm{~g} . \\
& \overline{2} \\
& 20.486 \mathrm{~g} . \\
& 54.830 \mathrm{~g} . \\
& 31.127 \mathrm{~g} . \\
& 11.24 \mathrm{a.m} . \\
& 2.069 \mathrm{l} .
\end{aligned}
$$

$22 \cdot 0^{\circ}$
Final

observation

(2. vii. 47)

$65.828 \mathrm{~g}$. Water absorbed $=2.336 \mathrm{~g}$.

$73.781 \mathrm{~g} . \quad 2.851 \mathrm{~g}$.

$41 \cdot 157 \mathrm{~g}$. $0.011 \mathrm{~g}$.$\} Total \mathrm{CO}_{2}=3 \cdot 110 \mathrm{~g} .=1 \cdot 583 \mathrm{l}$.

$40.351 \mathrm{~g} .0 .248 \mathrm{~g}$.

$60.795 \mathrm{~g}$. Water in faeces and on grid $=0.070 \mathrm{~g}$.

$69.725 \mathrm{~g}$. $\left\{\right.$ Total solids on grid $=0.281 \mathrm{~g} \cdot{ }^{*}$ (including

(faeces)

- $0.145 \mathrm{~g}$.

28.422 g. Urine $=0.772=0.622 \mathrm{~g}$. water $+0.150 \mathrm{~g}$. solid

$52 \cdot 200 \mathrm{~g}$. $\quad$ Water absorbed by residual food $=0 \cdot \mathrm{I} 86 \mathrm{~g}$. $52 \cdot 014 \mathrm{~g}$. $\left\{\right.$ Dry food eaten (and spilled) $=2 \cdot 3^{62} \mathrm{~g}$.

$18.035 \mathrm{~g}$. Water consumed $=2.451 \mathrm{~g}$.

$31.127 \mathrm{~g}$. (Initial wt. of mouse $=23.703 \mathrm{~g}$.) Average

$55.36 \mathrm{Ig}$. Final wt. of mouse $=24.234 \mathrm{~g}\} .23.968 \mathrm{~g}$.

- $\Delta W t=+0.531 \mathrm{~g}$.

I1.29 a.m. Duration $=24.08 \mathrm{hr}$.

$0.3641 . \quad \mathrm{O}_{8}=1 \cdot 7031$.

Calculated expansion of air in chamber $=$ $15 \mathrm{ml}$. $\mathrm{O}_{2}$ used $=1 \cdot 703$ +0.01 $5=1 \cdot 7181$. $=2.455 \mathrm{~g}$.

$\begin{array}{lll}- & - & 0.0635 \mathrm{~g} \\ - & - & 0.0007 \mathrm{~g} . \\ - & - & 0.0089 \mathrm{~g} .\end{array}$

Calculation of Exp. 9, day I

Weight balance $=\left(\mathrm{O}_{2}+\right.$ food + water consumed $)-\left(\right.$ water from mouse chamber $+\mathrm{CO}_{2}+$ moist faeces + urine + water absorbed by food)

$$
\begin{aligned}
& =(2.455 \mathrm{~g} .+2 \cdot 362 \mathrm{~g} .+2 \cdot 45 \mathrm{Ig} .)-(2 \cdot 336 \mathrm{~g} .+3.110 \mathrm{~g} .+0.35 \mathrm{I} \mathrm{g} .+0.772 \mathrm{~g} .+0.186 \mathrm{~g} .) \\
& =+0.513 \mathrm{~g} .
\end{aligned}
$$

Discrepancy from observed $\Delta W t=0.018 \mathrm{~g}$.

\section{Protein metabolism}

Urinary nitrogen $\quad=0.0635 \mathrm{~g}$.

Calories from protein $=0.0635 \mathrm{~g} . \times 30.59 \mathrm{Cal} . / \mathrm{g} .=\mathrm{I} \cdot 930 \mathrm{Cal}$.

$\mathrm{CO}_{2}$ from protein $=0.0635 \mathrm{~g} . \times 5.548 \mathrm{l} . \mathrm{g} .=0.352 \mathrm{l}$.

$\mathrm{O}_{2}$ from protein $=0.0635 \mathrm{~g} . \times 6.639 \mathrm{l} . \mathrm{g} .=0.422 \mathrm{l}$.

$\mathrm{H}_{2} \mathrm{O}$ from protein $=0.0635 \mathrm{~g} . \times 2.727 \mathrm{~g} . \mathrm{g} .=0.173 \mathrm{~g}$.

Total R.Q. $=\frac{1 \cdot 5831 .}{1 \cdot 7181 .}=0.921$

Non-protein R.Q. $=\frac{1 \cdot 5831 .-0.3521 .}{1 \cdot 7181 .-0.4221 .}=\frac{1 \cdot 2311 .}{1 \cdot 296 \mathrm{l} .}=0.95 \mathrm{r}$

Calorific value of $\mathrm{O}_{2}$ at this R.Q. $=4.986 \mathrm{Cal} . / \mathrm{l}$.

Total heat expenditure $=(\mathrm{r} \cdot 296 \mathrm{l} . \times 4 \cdot 986 \mathrm{Cal} . / \mathrm{l})+.\mathrm{I} \cdot 930 \mathrm{Cal} .=8 \cdot 393 \mathrm{Cal}$.

- This figure is large owing to dried urine; drainage was subsequently improved by altering the floor funnel.

$\dagger$ In this experiment the food was totally dried before use. 
Average metabolic rate $=\frac{8.393 \mathrm{Cal} . \times 24 \mathrm{hr} .}{23.968 \mathrm{~g} \cdot \times 24.08 \mathrm{hr} .}=0.349 \mathrm{Cal} . / \mathrm{g} .24 \mathrm{hr}$.

Carbohydrate and fat metabolized

At non-protein R.Q. 0.951 partitioning of $\mathrm{O}_{2}$ between carbohydrate and fat $=83.24: 16 \cdot 76$.

$\therefore$ Carbohydrate metabolized $=\frac{\times .2961 . \times 83.24}{100 \times 0.8291 . / \mathrm{g}}=\mathrm{r} \cdot 30 \mathrm{~g}$.

Water from carbohydrate $=1 \cdot 301 \mathrm{~g} \cdot \times 0.555 \mathrm{~g} \cdot \mathrm{g} \cdot=0.722 \mathrm{~g}$.

Fat metabolized $=\frac{1.2961 . \times 16.76}{100 \times 2.0151 . / \mathrm{g} .}=0.108 \mathrm{~g}$.

Water from fat $=0.108 \mathrm{~g} \cdot \times \mathrm{I} \cdot 094 \mathrm{~g} \cdot \mathrm{g} \cdot=0.118 \mathrm{~g}$.

\section{Foodstuffs ingested}

Dry food eaten and spilled $=2 \cdot 362 \mathrm{~g}$.

Nitrogen of food spilled $=0.0007 \mathrm{~g} \cdot=\frac{0.0007 \mathrm{~g} \cdot \times 100}{3.9}=0.018 \mathrm{~g} \cdot$ food

$\therefore$ Dry food eaten $=2 \cdot 344 \mathrm{~g}$.

Nitrogen ingested: 2.344 g. $\times 0.039=0.0914$ g. $(\equiv 0.583$ g. protein $)$

Fat ingested: $2.344 \mathrm{~g} . \times 0.103=0.241 \mathrm{~g}$.

Carbohydrate ingested: $2.344 \mathrm{~g} . \times 0.57 \mathrm{I}=1.339 \mathrm{~g}$.

Water ingested: $2.334 \mathrm{~g} . \times 0.008=0.019 \mathrm{~g}$.

Foodstuff losses in faeces

Weight of dry faeces $=0.145 \mathrm{~g}$.

$\therefore$ Faecal fat $=0.145 \mathrm{~g} . \times 0.015=0.002 \mathrm{~g}$.

Faecal carbohydrate $=0.145 \mathrm{~g} \cdot \times 0.263=0.038 \mathrm{~g}$.

Faecal nitrogen $=0.009 \mathrm{~g}$.

\section{Foodstuff balances}

Nitrogen $=0.091$ g. -0.009 g. -0.063 g. $=+0.019$ g. ( $\equiv 0.121$ g. protein)

Fat $=0.241$ g. -0.002 g. $-0.108 \mathrm{~g} .=+0.13 \mathrm{I} \mathrm{g}$.

Carbohydrate $=1.339 \mathrm{~g} .-0.038 \mathrm{~g} \cdot-\mathrm{I} \cdot 301 \mathrm{~g} .=0.000 \mathrm{~g}$.

Water balance

Positive

Metabolic water

Protein $0.173 \mathrm{~g}$.

Fat

$0.118 \mathrm{~g}$

Carbohydrate $\quad 0.722 \mathrm{~g}$.

In food

$0.019 \mathrm{~g}$.

Consumed

$2.451 \mathrm{~g}$.

Total $3.483 \mathrm{~g}$.

$\therefore \Delta$ Water $=+0.269 \mathrm{~g}$.

Negative

Absorbed by tube I

$2 \cdot 336 \mathrm{~g}$

In urine

$0.622 \mathrm{~g}$.

In faeces

0.0708.

Absorbed by residual food

$0.186 \mathrm{~g}$.

Total

3.2148. 